\title{
"Responsiveness of rural development to budget management attributes: Evidence from Ogun State, Nigeria"
}

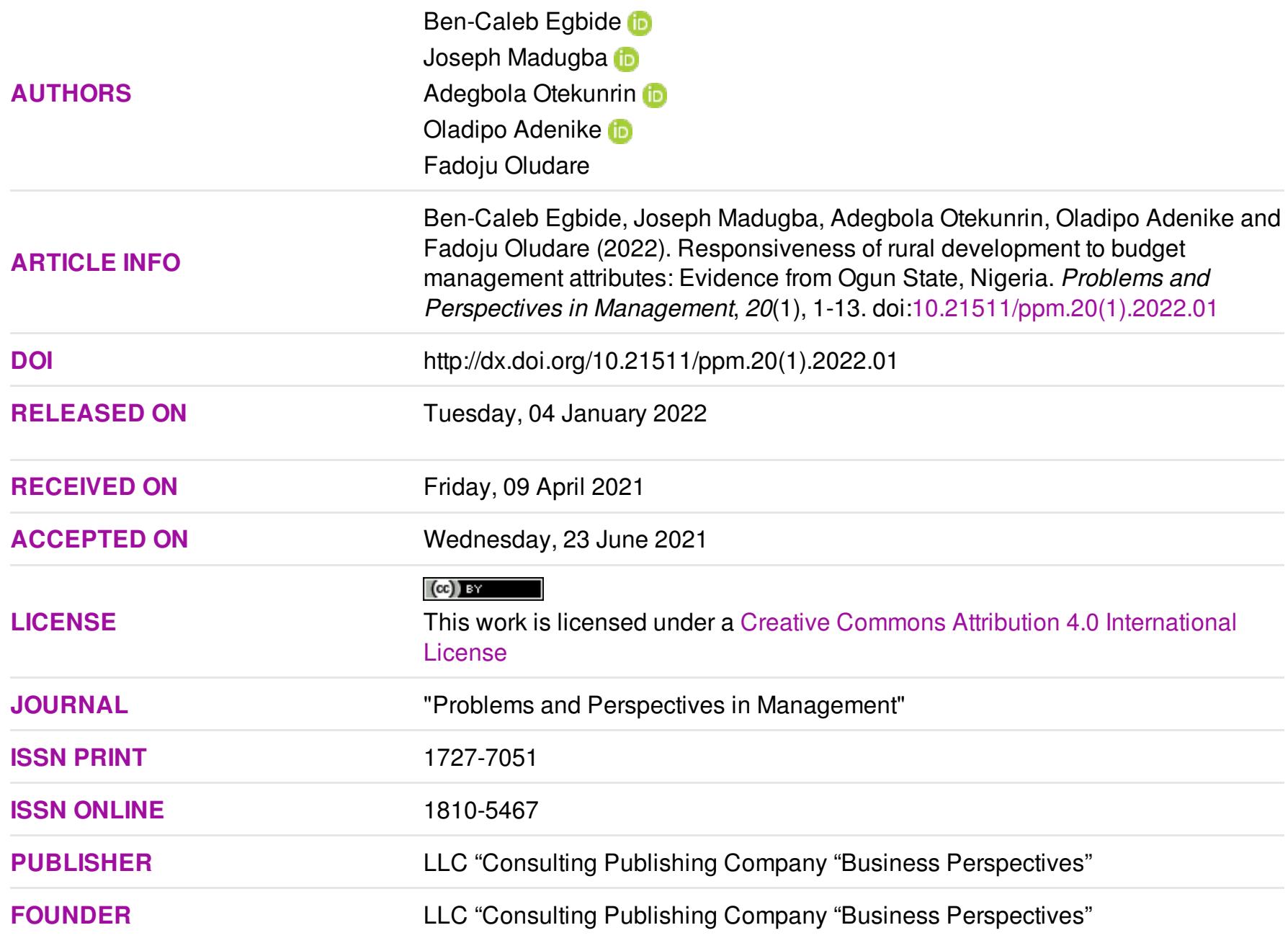

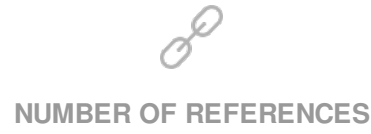

61

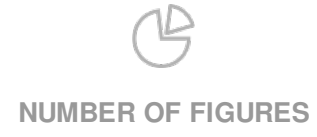

5
NUMBER OF TABLES

7

(C) The author(s) 2022. This publication is an open access article. 


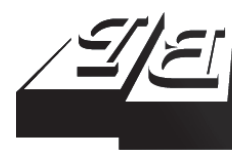

\section{BUSINESS PERSPECTIVES}

LLC "CPC "Business Perspectives" Hryhorii Skovoroda lane, 10, Sumy, 40022, Ukraine www.businessperspectives.org
Received on: $9^{\text {th }}$ of April, 2021 Accepted on: $23^{\text {rd }}$ of June, 2021 Published on: $4^{\text {th }}$ of January, 2022

(c) Ben-Caleb Egbide, Joseph Madugba, Adegbola Otekunrin, Oladipo Adenike, Fadoju Oludare, 2022

Ben-Caleb Egbide, Ph.D., Senior Lecturer, Accounting and Finance Department, College of Business and Social Sciences, Landmark University, Nigeria.

Joseph Madugba, Ph.D., Lecturer, Accounting and Finance Department, College of Business and Social Sciences, Landmark University, Nigeria.

(Corresponding author)

Adegbola Otekunrin, Ph.D., Senior Lecturer, Accounting and Finance Department, College of Business and Social Sciences, Landmark University, Nigeria.

Oladipo Adenike, Ph.D., Lecturer Department of Accounting and Finance, College of Business and Social Sciences, Landmark University, Nigeria.

Fadoju Oludare, MSc., Director, Financial Services, Bursary Department, Landmark University, Nigeria.
Ben-Caleb Egbide (Nigeria), Joseph Madugba (Nigeria), Adegbola Otekunrin (Nigeria), Oladipo Adenike (Nigeria), Fadoju Oludare (Nigeria)

\section{RESPONSIVENESS OF RURAL DEVELOPMENT TO BUDGET MANAGEMENT ATTRIBUTES: EVIDENCE FROM OGUN STATE, NIGERIA}

\begin{abstract}
The essence of local government as contained in the Nigerian Constitution is bring ing government closer to the people and make them feel the impact of governance. This study examined the responsiveness of rural development to three of the attributes of public budgeting (effectiveness, openness, and adequacy) in selected local governments in Ogun State, Nigeria. The objective was to establish the functional association and interconnectedness between the explained and explanatory variables. Data were gathered through the administration of a five-point Likert scale questionnaire distributed to 800 respondents in 8 local governments in Ogun States, out of which 348 , representing $43.5 \%$, were retrieved and used for analysis. Both descriptive statistics and ordinary least square regression were utilized in the study. The result showed that three explanatory variables, namely budget effectiveness, budget openness, and budget adequacy, are positively related to rural development, although the impact of budget adequacy was shown to be insignificant. The implication is that the effectiveness of budget management and the openness of the budget in terms of transparency and accountability are more responsive and influential determinants of rural development than the adequacy of the budget estimates. The paper, therefore, recommended improvement in budget openness through more consultations and accessibility to budget information by the public as well as monitoring of projects and programs within the local council to engender development and add value to the rural dwellers.
\end{abstract}

\section{Keywords effectiveness, openness, adequacy, transparency, development, Nigeria}

\section{JEL Classification $\quad$ M40, M41, M48, M49}

\section{INTRODUCTION}

One of the goals of business organizations is profit maximization, which can only be achieved through the proper utilization of the available resources(Olejniczak et al., 2020; Madugba et al., 2020). In the same manner, governments often plan how to allocate the available resources to effective use. This objective of the government can only be achieved through the use of a budget (Moseley, 2003; Neumeier, 2012). A budget is a series of coordinated estimates designed to forecast expected costs and results. It is a forecast or perhaps a prediction of future events usually based on records and quantified in monetary terms. Abdullahi and Angus (2012) asserted that government uses a budget as an instrument for forecasting and controlling its available funds. Effective use of budget entails determining the available resources and nature of expenditure annually.

Budgeting is as old as Man as recorded in the Holy Bible Genesis 41:3545 , where Joseph after the interpretation of the dream did a national budget for Egypt, which enticed Pharaoh and attracted his presiden- 
tial ascent without delay and by that budget, Egypt became a world power then. It is not out of place to say that budgeting must not be unobserved in the country that wishes to farewell economically with even development as demonstrated in the gospel of Luke 14:28-32, where Jesus taught of budgeting for a project before embarking on it and in Genesis 1:1-31our creator did budget and plan before commencing creation (Meador \& Skerratt, 2017; Binswanger, 1998; Madugba et al., 2020).

One major challenge of budgeting in Nigeria is effectiveness. Since the local government was created in 1976 and charged with the responsibility of chatting rural developments, various communities are still undeveloped. Lack of amenities for improved lifestyle has worsened in rural areas (Ogunkoya et al., 2015; Arowolo, 2008; Kluvers \& Tipett, 2010; Ebrahim, 2003; Goddard, 2005).

It is disparaging and heartbreaking that regardless of the federal and state allocations attributed to the local government including the internally generated revenue, there seems to be a disconnection between the resources expanded by the local government and the rural infrastructural development (health facilities, good roads, electricity, etc.). In other words, the observed trend of underdevelopment in some local government areas in Ogun State cast aspersion on how well resources budgeted to local government over the years had been utilized and/or accounted for and this necessitates a concern (Boggia et al., 2014; Suarez, 2019; Szesciło \& Wilk, 2018)

In Nigeria, rural development constitutes a fundamental problem (Eteng, 2005). It has been observed that the emphasis and priority given to rural development by the successive government since independence in 1960 have been more of rhetoric and lips service. Hence, it has not yielded the desired dividends, thereby creating a dangerous gap between urban and rural development in all development indices: economic, political, social, and infrastructural (Bhat et al., 2004; Ibenegbu, 2017; Madugba et al., 2020).

It is not out of place that the local government is the neighboring government to the rural dwellers with the abundant resources available to them have performed poorly and has nullified the crux of their establishment as contained in the 1979 Constitution of the Federal Republic of Nigeria. Hence, this motivated this study to examine the budget effectiveness, budget openness, and budget adequacy on rural development in selected local governments in Ogun State, Nigeria. Again, the non-availability of current literature on the matter is also a crucial factor that necessitated this study.

\section{LITERATURE REVIEW}

Olomola (2012) asserted that the budget is a vital economic tool of national resources mobilization, allotment, and economic administration. It helps to make possible and realize the vision of government in a given financial year. Weihrich and Koontz (2003), as cited in Ben-Caleb and Agude (2015), stated that effectiveness is the extent to which an objective is achieved. Horngren (2013) opined that effective implementation of the budget is measured by the difference between the actual and budgeted performance. Permit to say that budget effectiveness is vital for a successful organization. Effective budgeting is a process whereby the objectives and goals of the public sector can be achieved. It entails allocating and using the resources within the public sector appropriately. Osanyintintuyi (2007) stated that the major budgeting goal is to improve the lives of individuals in the country through the provision of employment, schools, affordable healthcare, assessable roads, and reduction of poverty.

Osanyintintuyi (2007) claimed that development is an adjustment in individual fulfillment (not just material lifestyle) in both subjective terms. Rural development is a bond-together strategy to sustenance age, arrangement of physical, social, and institutional establishment with an extreme goal of accomplishing incredible restorative administration, direct and quality preparing developed and sustainable agriculture, etc. Some features of rural areas include abject poverty, lack of clean water, 
lack of accessible roads, improper housing, high level of illiteracy, lack of conducive environment, large family, lack of power supply, lack of appropriate health care, etc. This is a paramount everywhere in Nigeria, in both the so-called urban and rural areas, and it discourages the youths who account for the active labor force to reside in such areas. Okoli and Onah (2002) asserted that budget effectiveness helps the authorities in charge of the resources for rural development monitor and control the usage of these resources effectively and efficiently to accomplish the fixed goals of the local government in developing rural areas. Adedayo (2000) and Kariuki (2010) pended that budget effectiveness helps the government to remain focused on its plan and strategy having an idea of the areas to spend resources. In addition, it assists in controlling inaccurate projections and minimizing the discrepancies between the standard and actual results.

Budget openness encompasses a wide range of practices and interventions aimed at promoting transparency, participation, accountability, and legislative oversight to ensure that government spending reflects the peoples' needs and interests. Fiscal transparency is all about being open to the public in general regarding the organization and functions of the government, fiscal policy expectations, public sector accounts, and fiscal projections. These projections should also capture the needs of those in a rural area of Nigeria (Osanyintuyi, 2007). Policy transparency, on the other hand, implies being open to the public about what government goals are in a specific policy area, in which results are to be accomplished and the expenses of accomplishing such results (Adebayo, 2014). However, the accuracy and timeliness of reporting genuine performance with excellent output and results accomplished are a key part of the lucidity required for effective budget execution in the local government sector that will improve the development of rural dwellers. Accessibility to good quality and wide-ranging information on the budget evaluation and actual spending is required consistently for significant examination and translation by interested parties. A budget analyst should create valuable contributions into policy decision-making for promoting change in the budget process (Abogun \& Fagbemi, 2012).
Budget adequacy implies the ability of a budget to satisfy its basic requirement. It also means the level of perception of leaders that the established budget is satisfactory to carry out work activities that will support the achievement of corporate objectives. It is crucial to state that the perception of the satisfactory nature of a budget by top management personnel affects the performance of the budget (Khaddafi et al., 2015). Horny (2000), as cited in Adebayo (2014), opined that rustic advancement guarantees the modernization of the rural culture and the modification from its conventional disconnection to incorporate with the nationwide budget. Despite devout authority and declaration of expectation as contained in the improvement designs, toward the end of each arrangement period, rural life stayed unaffected. Budget adequacy will help in improving rural development. However, if the public budget satisfies its requirement to the public, which includes the building of roads, infrastructures, provision of employment, etc., this will, in turn, improve the developing rural region.

Local government councils have been recognized as the third tier of governmental organization in Nigeria since 1976. Consequently, its functions and roles in economic management are well defined and stated in the 1999 Constitution of the Federal Republic of Nigeria. These roles and functions include construction and maintenance of roads, streets, etc., as may be prescribed from time to time by the house of assembly of the state (Federal Republic of Nigeria, 1999). Besides, it is the role of LGAs to establish slaughterhouses, slaughter slabs, markets, motor parks, and public convenience.

The major sources of revenue available to local governments in Nigeria are internal and external revenues (Alo, 2012 cited in Agba et al., 2014). The internally generated revenue is revenue that accrues to the local government from within its environs. Such include community and poll taxes or tenement rates. They can as well build stores and shopping malls, renting LG properties like reception halls, chairs, canopies, tables, etc. (Ajayi, 2000). This type of revenue is the major avenue for financing local government projects through the quantity of it is a function of revenue will and size of the LGA and course nature of operations in 
such LGAs (Agba et al., 2014; Atakpa et al., 2012; Olaoye, 2010).

The external sources of revenue for LGAs include funds gotten not being within the LGAs. To be specific, section 7 (6a-b) of the 1999 Constitution of the Federal Government of Nigeria permits allocation to the LGAs, and currently, this serves as a major avenue to LGAs in Nigeria. Based on the 1979 allocation formula, it specifically stated $10 \%$, whereas in 1991 it was 15\%, $1992-20 \%$, and since 2004 it has been 20.6\% (Onuigbo \& Eme, 2015).

Although it had been argued that the revenue allocations to LGAs in Nigeria are grossly inadequate, yet even the meager amounts are in most cases hijacked by the states. Thus, crippling the development endeavors of the local councils.

Alo (2012) found that budget help in mobilization and proper utilization of resources to achieve that set goals in every organization and that budget serve as a guide as it eliminates waste of resources.

Jatau (2008) argued that the major cause of poor performance in the third tier (local government) is lack of budget effectiveness and that the best of the expectancies of what the local government areas stand to offer, the place of financial appropriations and allocation cannot be exonerated.

Igboeche (2017) employed an explanatory research model and descriptive design and found that the major challenge of budget effectiveness in Nigeria is over-reliance on petro-dollar income. It was suggested that Nigeria ought to diversify its economy as to create a healthy nation.

Nwankpa and Okeke (2017) examined the issue of budgeting for change in the Nigeria Public sector and found that the Nigerian budget is characterized by procedural indiscipline and a series of implementation crises.

Uchechukwu and Obiora (2016) were motivated to find out how local governments can identify revenue sources available to them and ensure effective management of their finances to enhance rural development. The study found that effective utilization of local government finances has a significant effect on rural development and a solid base has a significant effect on the enhancement of rural development.

Uguru (2016) scrutinized the effect of the instrument of control on public accountability in local government councils of Ebonyi State. It was found that a significant effect of the instrument of control on the public accountability in local councils of Ebonyi State.

Sam-Tsokwa and Ngara (2016) examined the deficiencies in the public sector budgetary process in Nigeria and found that the ability to make timely and sensible fiscal choices is one of the hallmarks of good governance.

Stotsky (2016) in a similar study found that the goal of gender budgeting in its broadest concept is actually to integrate gender-oriented concern into fiscal policies and administration. It was concluded that gender budgeting should not focus only on females but also on the male with an emphasis in developing countries.

Ben-Caleb and Agude (2013) examined public budgeting and poverty reduction in Nigeria. It was found that budget allocations in Nigeria have a negative but significant relationship with the poverty index, budget discipline does not influence the poverty index, and budget reforms do not have any significant relationship with the poverty index. Meanwhile, a significant association was noticed between operational efficiency and the poverty index in Nigeria.

Boris (2015) examined the challenges confronting local government administration in effective and efficient services delivery at the grassroots and found that lack of funds, corruption, and undue political interference amongst other major constraints to local government hinder service delivery.

An integrated approach to rural development in Nigeria was investigated by Ogunkoya et al. (2015). The study adopted time series data and found that the greater part of the public effort on rural development has subsumed under agricultural development, which was more exploitative to rural resources and dwellers than improve their quality of life. 
Rabiu et al. (2015) explored budget process review and organizational performance in small firms in Nigeria and found that the budget process in small firms in Nigeria is a total failure in the sense that they do not employ budget in their management of affairs of the business.

Olaoye (2010) in a study on budget effectiveness in Nigeria found that the Nigerian budget has not lived up to expectation (on annual basis) because the embedded process has been abandoned to the whims and caprice of bureaucrats and politicians.

Adebayo (2014) explored local government and the challenges of rural development in Nigeria from 1999 to 2014. The study found that the problem facing most local governments is the lack of adequate finance to implement various programs in rural areas. This was corroborated by Iwala (2014) who found that the creation of more jobs will reduce poverty in Nigeria.

Pau et al. (2014) exploited rural development programs and the challenges of rustic underdevelopment in Nigeria and found that rustic development programs exist on paper and their effects are not been felt by the assumed recipients.

Ben-Caleb and Agbude (2013) found that budget discipline under the democratic regime is far better than budget discipline under the military regime.

Egwemi et al. (2013) stated that Nigeria as a nation has failed to explore the root of underdevelopment and poverty in all the budgets.

Okpanachi and Muhammed (2013) examined budget target setting and effective performance. Findings revealed that the budget target setting procedure in the hotel in Kaduna State is not well articulated and focused and that target setting is an effective way for performance evaluation of individuals and units in the hospitality industry.

In a similar study, Onuigbo and Eme (2015) found that the information technology application of computerized accounting systems contributes to the budget process at a higher magnitude than the size of the firm. The study suggested that SMEs should involve relevant stakeholders in implementation budgets to ensure their success.
Ehigiamusoe and Umar (2013) re-examined the role of legislative oversight in budget performance in the country (Nigeria) and found that oversight has increased tremendously since 1999; but they were not very effective in reducing corruption and accelerating the budget of ministries, departments, and agencies.

Ugwuanyi and Ebi (2012) adopted content analysis in Enugu State. It was estimated that there is a poor accounting practice in government-owned establishments that hinders the proper budgetary execution, which is hardly kept by those establishments.

Kpedor (2012) found that major actors do not comply with budgets hence, monthly performance reports do not get down to the project managers. This finding is supported by Nwagboso and Duke (2012), and Ojeh et al. (2012).

It is evident from the empirical studies reviewed that there is no study of this nature in Nigeria. Consequently, this study is designed to investigate the responsiveness of rural development to budget management attributes regarding Ogun State, Nigeria. While the specific objective is to examine the effect of budget openness, budget adequacy, and budget effectiveness on rural development in Ogun State, Nigeria.

\section{DATA AND METHODOLOGY}

Data for this study were garnered from a structured five-point Likert scale questionnaire, administered to a cross-section of 400 respondents in eight selected local government councils in Ogun State.Based on the projected population estimate in 2016, the eight selected local government areas have a population of 2,749,500 distributed as thus: Abeokuta North - 276,500; Abeokuta South - 348,200; Ado-Odo/Ota - 733,400; IjbuOde - 218,600; Oba Femi-Owodo - 327,000; Yewa South - 234,200; Yewa North - 255,700; and Sagamu - 355,900. With the total population of the whole State estimated at 3,751,140, the eight LGAs constitute about $73 \%$ of the state population. Consequently, a sample of 400 respondents was drawn from the population of the eight LGAs applying Slovin's sampling estimation formula giv- 
en as $n=N /\left(1+N e^{2}\right)$ with an error-tolerant of $5 \%$ (Glen, n.d.).

The data collected were analyzed using a combination of descriptive statistics and inferential statistics. The attributes of the data were described by determining their minimum, maximum, mean, and standard deviation. The data were tested for reliability, normality, and outliers as precursors for conducting inferential statistics. The KolmogorovSmirnov test and the histogram were utilized in testing the normality while the box-plot was adopted for testing for outliers. The test of reliability was conducted to ensure that the questions "hang-together" and are all measuring the construct intended. The Cronbach's alpha coefficient was utilized in gauging the internal consistency of the questions since it is the most commonly used indicator of consistency (Pollant, 2001). Table 1 shows the Cronbach's alpha coefficient of 0.695 , which is approximately 0.7 , indicating that the scale meets the reliability benchmark.

According to Table 1, Cronbach's alpha for budget effectiveness is 0.681 , budget openness is 0.716 , budget adequacy is 0.689 , and rural development is 0.574 . Except for rural development, all are approximately 0.7 , which is the thresh hold for the reliability test (Pollant, 2001). However, since the items on the scale are less than 10, the inter-item correlation was also tested. Table 1 shows that the inter-item coefficient is above 0.4 indicating or demonstrating support for the reliability of the instrument.
To achieve the aim of this study, the model is specified as (1) and (2).

$R E D E V=(B U D E F F, B U D O P E N$, $B U D A D E Q)$,

$R E D E V_{i t}=f\left(\beta_{0}+\beta_{1} B U D E F F+\right.$

$\left.+\beta_{2} B U D O P E N+\beta_{3} B U D A D E Q\right)$,

where $R E D E V$ is rural development; $B U D E F F$ is budget effectiveness; BUDOPEN is budget openness; and $B U D A D E Q$ is budget adequacy.

\section{ANALYSIS AND RESULTS}

\subsection{Descriptive statistics of the respondents}

Table 2 shows the descriptive statistics of the respondents. 205 of the respondents are male and this represents about $58.9 \%$ of the total responses received. While 143 of the respondents representing $41.1 \%$ are females. 48 of the respondents are civil servants on grade level $0-7$, which is $13.8 \%$. $205(58.9 \%)$ of the respondents are grade level 8-11, while 95 representing $27.3 \%$ are in grade level 12 and above. 25 of the respondents are senior school certificate holders, which is $7.2 \%$. National Diploma/NCEholders are 89 respondents (25.6\%);B.SC/HND - 145 (41.7\%); Masters of Arts/Science and business administration are 51

Table 1. Reliability test

Source: Authors' elaboration.

\begin{tabular}{|c|c|c|c|c|}
\hline No. & Composite variable & No of items in a scale & Cronbach's alpha & Corrected item-total correlation \\
\hline \multirow{4}{*}{1} & \multirow{4}{*}{$B U D E F F$} & \multirow{4}{*}{4} & \multirow{4}{*}{0.681} & 0.447 \\
\hline & & & & 0.498 \\
\hline & & & & 0.505 \\
\hline & & & & 0.406 \\
\hline \multirow{4}{*}{2} & \multirow{4}{*}{ BUDOPEN } & \multirow{4}{*}{4} & \multirow{4}{*}{0.716} & 0.534 \\
\hline & & & & 0.540 \\
\hline & & & & 0.467 \\
\hline & & & & 0.474 \\
\hline \multirow{4}{*}{3} & \multirow{4}{*}{$B \cup D A Q C$} & \multirow{4}{*}{4} & \multirow{4}{*}{0.689} & 0.479 \\
\hline & & & & 0.497 \\
\hline & & & & 0.459 \\
\hline & & & & 0.457 \\
\hline \multirow{4}{*}{4} & \multirow{4}{*}{ REDEV } & \multirow{4}{*}{4} & \multirow{4}{*}{0.574} & 0.162 \\
\hline & & & & 0455 \\
\hline & & & & 0.496 \\
\hline & & & & 0.365 \\
\hline
\end{tabular}


(14.7\%); while Doctor of Philosophy is 38 respondents representing $10.9 \% .54$ of respondents (15.5\%) are civil servants with 0 -10 years of work experience, 99 (28.4\%) are between 11-20, 120 (34.5\%) are between 21-30 years of work experience while 7 are between 31 years and above representing 21.6\%. 52 respondents are from Abeokuta North (14.8\%), 41 are from Abeokuta South (11.8\%),35 - Ado-Odo/Ota (10.1\%), 44 - Ijbu-Odo (12.6\%), 61 - Oba-Femi-Owodo (17.5\%), 49 - Yewa South (14.9\%), 31 - Yewa North (8.9\%) while 35 respondents come from Sagamu (10.1\%).

Table 2. Descriptive statistics of respondents

Source: Authors' elaboration.

\begin{tabular}{|c|c|c|c|}
\hline Data & Respondents & Frequency & Percentage \\
\hline Number $(\mathrm{N})$ & Total & 348 & 100 \\
\hline \multirow{2}{*}{ Gender } & Male & 205 & 58.9 \\
\hline & Female & 143 & 41.1 \\
\hline \multirow{3}{*}{ Grade level } & $0-7$ & 48 & 13.8 \\
\hline & $8-11$ & 205 & 58.9 \\
\hline & 12 and above & 905 & 27.3 \\
\hline \multirow{5}{*}{$\begin{array}{l}\text { Educational } \\
\text { qualification }\end{array}$} & SSCE & 25 & 7.2 \\
\hline & ND/NCE & 89 & 25.6 \\
\hline & BSC/HND & 145 & 41.7 \\
\hline & $\mathrm{MA} / \mathrm{MSC} / \mathrm{MBA}$ & 51 & 14.7 \\
\hline & Ph.D. & 38 & 10.9 \\
\hline \multirow{4}{*}{$\begin{array}{l}\text { Length } \\
\text { of service }\end{array}$} & $0-10$ & 54 & 15.5 \\
\hline & $11-20$ & 99 & 28.4 \\
\hline & $21-30$ & 120 & 34.5 \\
\hline & 31 and above & 7 & 21.6 \\
\hline \multirow{8}{*}{$\begin{array}{l}\text { Local } \\
\text { government } \\
\text { area }\end{array}$} & $\begin{array}{l}\text { Abeokuta North } \\
\text { Local Government }\end{array}$ & 52 & 14.2 \\
\hline & $\begin{array}{l}\text { Abeokuta South } \\
\text { Local Government }\end{array}$ & 41 & 11.8 \\
\hline & $\begin{array}{l}\text { Ado-Odo/Ota Local } \\
\text { Government }\end{array}$ & 35 & 10.1 \\
\hline & $\begin{array}{l}\text { ljbu-Odo Local } \\
\text { Government }\end{array}$ & 44 & 12.6 \\
\hline & $\begin{array}{l}\text { Oba-Femi-Owodo } \\
\text { Local Government }\end{array}$ & 61 & 17.5 \\
\hline & $\begin{array}{l}\text { Yewa South Local } \\
\text { Government }\end{array}$ & 49 & 14.1 \\
\hline & $\begin{array}{l}\text { Yewa North Local } \\
\text { Government }\end{array}$ & 31 & 8.9 \\
\hline & $\begin{array}{l}\text { Sagamu Local } \\
\text { Government }\end{array}$ & 35 & 10.1 \\
\hline
\end{tabular}

\subsection{Descriptive statistics of responses}

Evidence from Table 3 showed the minimum and maximum values of 1 and 5 for all the questionnaires distributed. This is based on the five-point Likert scale used with a minimum value of 1 and a maximum value of 5 . Lack of budget effectiveness impedes rural development showed the mean value of 3.1065 indicating that the majority of the respondents agree that lack of budget effectiveness impedes rural development in Nigeria. A standard deviation of 1.08133 was also shown.

Again, a mean value of 3.4260 implies that a greater number of the total respondents agreed that there is no budget openness and hence it delays rural development negatively in the local government system. The standard deviation value of 0.99209 was also recorded.

The mean value of 2.3973 implies that a greater number of the total respondents agreed that lack of budget adequacy is a major impediment to rural development in Ogun State, Nigeria. This is further supported by a standard deviation of 1.346.

Table 3 shows that a mean of 2.3973 was indicated implying that a preponderance number of the total respondents agreed that rural development is negatively affected by lack of budget effectiveness, openness, and adequacy in Ogun State and the standard deviation value of .78854 was also recorded.

Table 3. Descriptive statistics for attributes of budget characteristics

Source: Authors' elaboration

\begin{tabular}{l|c|c|c|c}
\hline Variable & Min & Max & Mean & $\begin{array}{c}\text { Standard } \\
\text { deviation }\end{array}$ \\
\hline$B U D E F F$ & 1 & 5 & 3.1065 & 1.08133 \\
BUDOPEN & 1 & 5 & 3.4260 & 0.99209 \\
\hline$B \cup D A D E Q$ & 1 & 5 & 2.3944 & 0.95324 \\
\hdashline REDEV & 1 & 5 & 2.3973 & 0.78854 \\
\hline \multicolumn{4}{c}{}
\end{tabular}

\subsection{Normality test}

The skewness for BUDEFF -.117, and Kurtosis -.886 , was shown signifying that comparatively is not normally dispersed, this could be due to the sample size of the study (348) (Tabachnick \& Fidell, 2001; Pollant, 2001). The ordinariness position of BUDEFF data is shown in Figure 1. There is a bell-shaped curve that implies the routine of the figures.

For budget openness (BUDOPEN), the analysis for Skewness indicated a value of 0.656 and this 


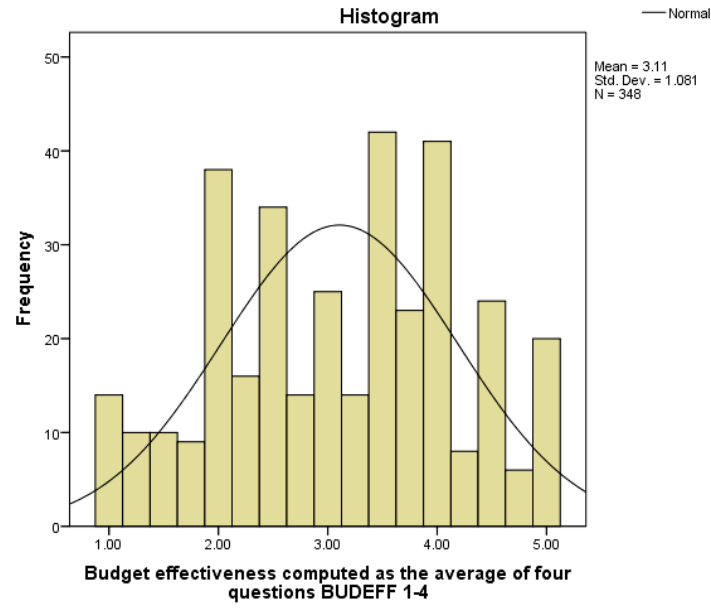

Figure 1. Normality distribution for BUDEFF

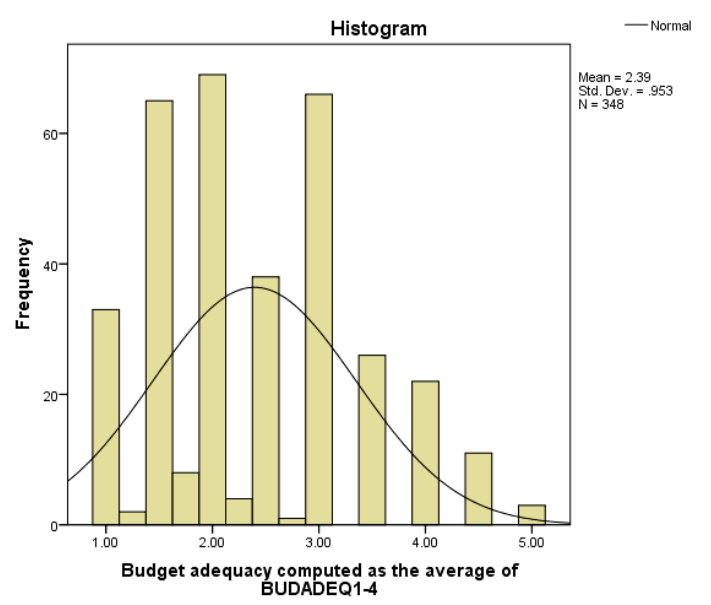

Figure 3. Normality distribution for $B U D A D E Q$

means that BUDOPEN is positively skewed and not far from zero. The Kurtosis revealed a value of 1.820 , signifying that it is peaked. Figure 2 shows the histogram that is a bell shape curve.

Budget adequacy (BUDADEQ) displayed a Skewness value of -0.454 , Kurtosis value of -0.308 , indicating relative peakedness. The histogram in Figure 3 is a bell-shaped curve that shows the normality of the data.

Rural development (REDEV) displayed a Skewness value of -0.506 , while the Kurtosis for REDEV is -0.465 . Figure 4 illustrates the histogram indicating that the data is well presented.

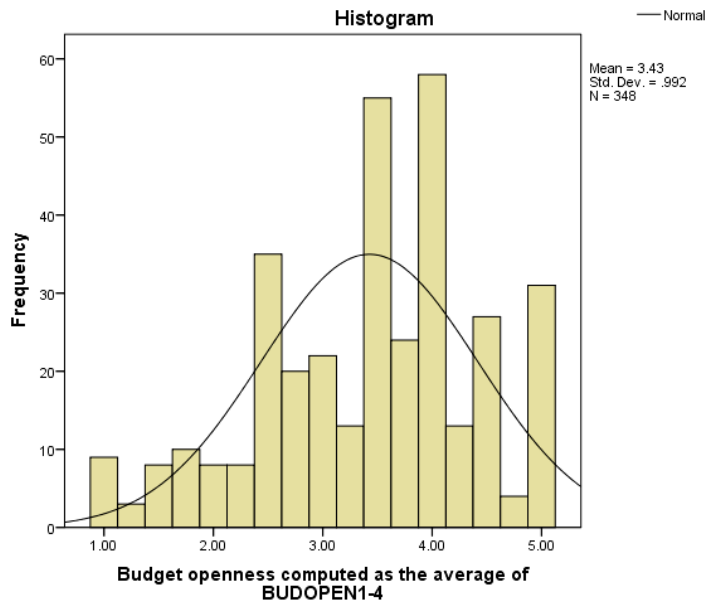

Figure 2. Normality distribution for BUDOPEN

Source: Authors' elaboration.

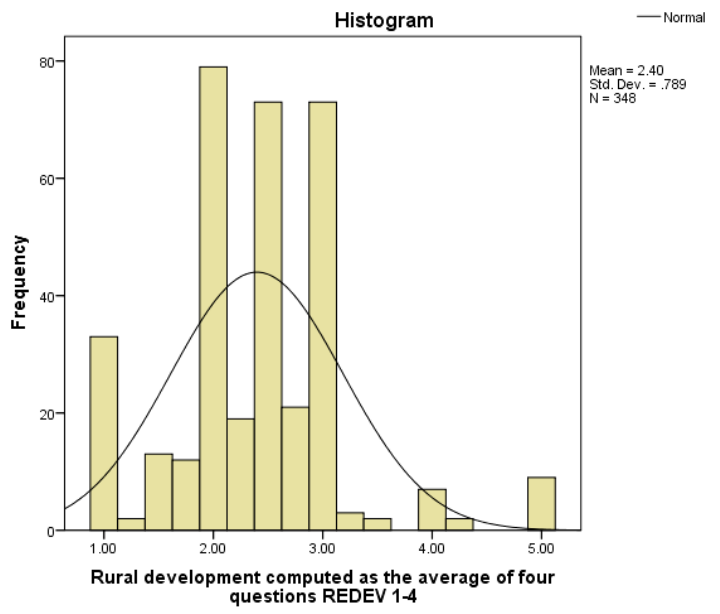

Figure 4. Normality distribution for REDEV

\subsection{Test for outliers}

Figure 5 showed that there is an outlier, but such an outlier is not enough to undermine the results of this study (Pollant, 2001). Therefore, no data case will manipulate the result.

\subsection{Multi-collinearity testing}

As disclosed in Table 4, the tolerance significance of $0.854,0.857$, and 0.984 is not as up to 0.10 , meaning that the law of multicollinearity assumptions is not undermined. This is collaborated by the variance inflation factor (VIF) values of 1.170, 1.167, and 1.016, which is lesser than the cut-off of 10 (Pollant, 2001). 


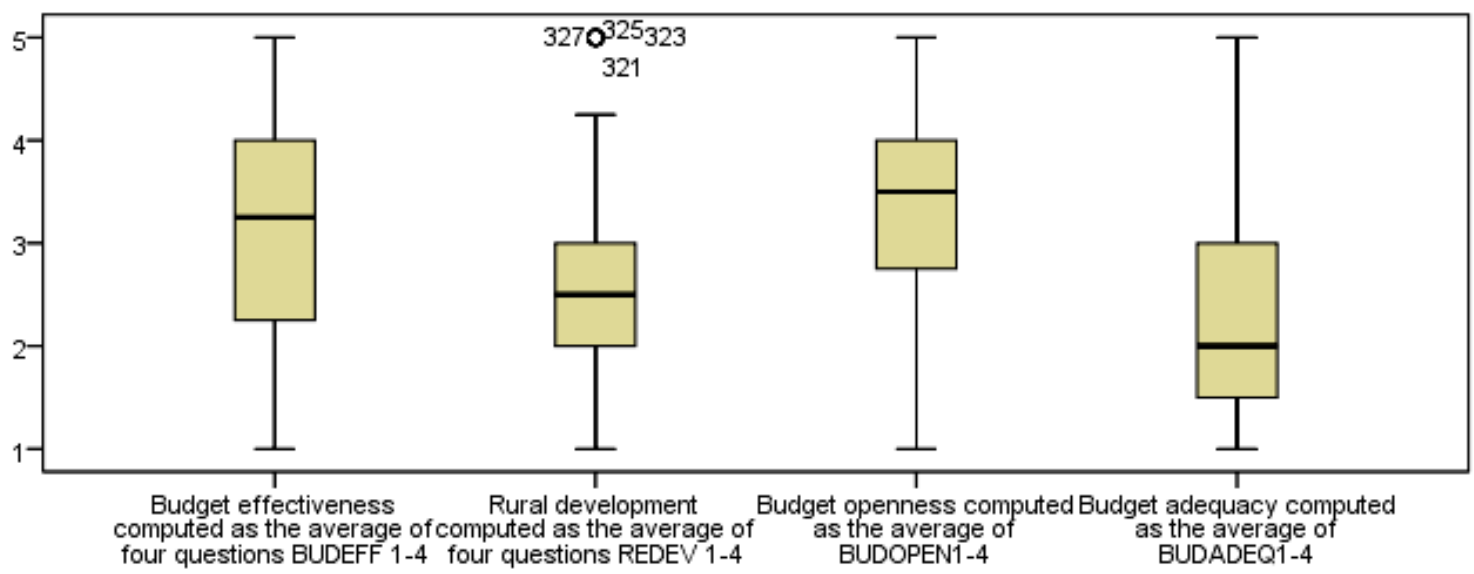

Figure 5. Box plot on outliers for characterization of the budget

Table 4. Results of the multi-collinearity test

Source: Authors' elaboration.

\begin{tabular}{l|c|c}
\hline \multicolumn{1}{c|}{ Variable } & Tolerance & Variance inflation factor (VIF) \\
\hline BUDEFF & 0.854 & 1.170 \\
\hdashline$B \cup D O P E N$ & 0.857 & 1.167 \\
\hline BUDADEQ & 0.984 & 1.016 \\
\hline
\end{tabular}

\subsection{Hypothesis testing}

Following the aim of this study, the following hypothesis is formulated:

H1: There is no significant relationship between budget effectiveness, budget openness, and budget adequacy, and rural development in the selected local government area of Ogun State, Nigeria.

It is decided to accept the hypothesis if the probability value computed by using SPSS is greater than or equal to 0.05 (i.e. $P \leq 0.05$ ).
Table 5 shows that the correlation (R) is $22.6 \%$ meaning there is an optimistic bond amid the $R E D E V$ and the expounding variables. The coefficient of determination of $5.1 \%$ is equally positive and pointing to those predictor variables (BUDEFF, BUDOPEN, and BUDADEQ) could explain about $5.1 \%$ of the variations in REDEV. This result indicates that rural development is to an extent determined by the characterization of the budget in Nigeria as measured by budget effectiveness, openness, and adequacy. In other words, the more lack budget effectiveness, budget openness, and budget adequacy, the more rural development suffers. The Durbin-Watson value of 1.640 , which

Table 5. Model summary ${ }^{b}$

\begin{tabular}{c|c|c|c|c:c}
\hline Model & $\mathbf{R}$ & $R$-square & Adjusted $R$-square & Std. error of the estimate & Durbin-Watson \\
\hline 1 & $.226^{\mathrm{a}}$ & .051 & .043 & .77141 & 1.640 \\
\hline
\end{tabular}

Note: a means predictors: (constant) BUDEFF BUDOPEN, BUDADEQ; b means dependent variable: REDEV.

Table 6. ANOVA

\begin{tabular}{|c|c|c|c|c|c|c|}
\hline & Model & Sum of squares & df & Mean square & $\mathbf{F}$ & Sig. \\
\hline \multirow{3}{*}{1} & Regression & 11.060 & 3 & 3.687 & 6.195 & $.000^{b}$ \\
\hline & Residual & 204.705 & 344 & .595 & - & - \\
\hline & Total & 215.765 & 347 & - & - & - \\
\hline
\end{tabular}

Note: a means dependent variable: REDEV; b means predictors: (constant). BUDADEQ, BUDOPEN, BUDEFF. 
Table 7. Regression analysis of the hypothesis

\begin{tabular}{|c|c|c|c|c|c|c|}
\hline & \multirow{2}{*}{ Model } & \multicolumn{2}{|c|}{ Unstandardized coefficients } & \multirow{2}{*}{$\frac{\text { Standardized coefficients }}{\text { Beta }}$} & \multirow{2}{*}{$\mathbf{T}$} & \multirow{2}{*}{ Sig } \\
\hline & & B & Std. error & & & \\
\hline \multirow{4}{*}{1} & (Constant) & 1.631 & .185 & - & 8.799 & .000 \\
\hline & $B U D E F F$ & .092 & .041 & .126 & 2.216 & .027 \\
\hline & BUDOPEN & .085 & .045 & .107 & 1.892 & .059 \\
\hline & $B \cup D A D E Q$ & .079 & .044 & .095 & 1.800 & .073 \\
\hline
\end{tabular}

Note: a means dependent variable: rural development.

is just about 2, signifies the nonappearance of au- and Uguru (2016).

tocorrelation in the distribution.

Table 6 shows that F-statistics is 6.195 while the significant value is $0.000<0.05$ level of significance. This outcome is momentous and indicates that the model is a good fit. Thus, the predictor variable mutually and considerably affects the reliant variable (REDEV).

Evidence from Table 7 indicates that budget effectiveness $(B U D E F F)$ has a positive and significant impact on rural development in selected local governments in Ogun State ( $t$-value of 2.216 and probability value of 0.027$)$. This finding corroborates the studies of Uchechukwu and Obiora (2016),

Budget openness (BUDOPEN) is found to have a positive and significant impact on rural development in selected local governments of Ogun State, Nigeria, as validated by a $t$-value of 1.892 , and a probability value of .059. Again, this finding agrees with Nwagboso and Duke (2012), Ojeh et al. (2012), and Kpedor (2012).

Table 7 also indicated that budget adequacy (BUDADEQ) has a positive but significant impact on rural development in Nigeria with a $t$-value of 1.800 and a probability value of 0.079 . The studies of Ugwuanyi and Ebe (2012) validated this finding.

\section{CONCLUSION}

Good governance is the aftermath of budget effectiveness, budget openness, and budget adequacy. This study was motivated to find out why rural areas despite the proximity of the local governments to them cannot feel the impact of the government. To achieve the objective, data were gathered through a questionnaire distributed to eight local governments. A hypothesis was formulated and tested using regression with the aid of SPSS 23. Evidence from Table 7 showed that the coefficient of regression and their probability values are BUDEFF 0.092 (.027), BUDOPEN 0.085 (.059), BUDADEQ 0.079 (.073) indicating that budget effectiveness and budget openness have a positive and significant impact on rural development. However, budget adequacy was found to be positive but insignificant with rural development in selected local governments of Ogun State, Nigeria. The study, therefore, concludes that there is a significant association between budget attributes and rural development in local governments in Nigeria. However, this is without prejudice to whether the funds allocated to them as contained in the budget get to them and are used for what it is meant.

From the conclusion, there is an urgent need to consult with the people in budget preparation to know the needs of people hence channel resources effectively. Again, there is a need for effective monitoring to ensure the eradication of fund diversion in the government.

\section{AUTHOR CONTRIBUTIONS}

Conceptualization: Ben-Caleb Egbide, Joseph Madugba, Adegbola Otekunrin, Oladipo Adenike, Fadoju Oludare.

Data curation: Ben-Caleb Egbide, Joseph Madugba, Adegbola Otekunrin. 
Formal analysis: Ben-Caleb Egbide, Joseph Madugba, Oladipo Adenike, Fadoju Oludare. Methodology: Joseph Madugba, Adegbola Otekunrin, Oladipo Adenike, Fadoju Oludare. Supervision: Ben-Caleb Egbide, Adegbola Otekunrin, Fadoju Oludare. Writing - original draft: Ben-Caleb Egbide, Joseph Madugba, Adegbola Otekunrin. Writing - review \& editing: Ben-Caleb Egbide, Joseph Madugba, Oladipo Adenike, Fadoju Oludare.

\section{REFERENCES}

1. Adedayo, O.A. (2000). Understanding Statistics. Lagos: JAS Publishers.

2. Abdullahi, A.M., \& Angus, O.U. (2012). Budget in Nigeria Public Sector: Need for Balanced Scorecard Perspective. International Journal of Finance and Accounting, 1(2), 1-6. https:// doi.org/10.5923/j.ijfa.20120102.01

3. Abogun, S., \& Fagbemi, T. O. (2012). The Efficacy of Budgeting as a Control Measure in Developing Economies. A Study from Nigeria. Journal of Asian Social Science, 8(1). https://doi. org/10.5539/ass.v8n1p176

4. Adebayo, A. S. (2014). Local Government and the Challenges of Rural Development in Nigeria (1999 to date). IOSR Journal of Humanities and Sciences, 19(4), 98-107. https://doi. org/10.9790/0837-194198107

5. Agba, S. M., Stephen, O., \& Nnamani, O. D. (2014). Local Government Finance in Nigeria:Challenges and Prognosis for Action in a Democratic Era (1999-2013). Journal of Good Governance and Sustainable Development in Africa, 2(1), 84-96. Retrieved from https:// www.semanticscholar.org/ paper/Local-GovernmentFinance-In-Nigeria\%3AChallenges-and-Agba-Stephen/ c985a80866065f1728305ac74b618d9b26c3bd42

6. Ajayi, K. (2000). Theory and Practice of Local Government. Ado-Ekiti: University of Ado-Ekiti.

7. Alo, E. N. (2012). Fiscal federalism and local Government finances in Nigeria. Word Journal of education, 2(5), 19-27. https://doi. org/10.5430/wje.v2n5p19

8. Arowolo, D. (2008). Local Government Administration and
Challenges of Rural Development in Nigeria. IOSR Journal of Humanities and Social Science (IOSR-JHSS), 19(4), 21-32.

9. Atakpa, M., Ocheni, S., \& Nwankwo, B.C. (2012). Analysis of Options for Maximizing Local Government Internally Generated Revenue in Nigeria. International Journal of Learning and Development, 2(5), 94-104. https:// doi.org/10.5296/ijld.v2i5.2345

10. Ben-Caleb, E., \& Agude, G. A. (2013). Budget Discipline in Nigeria: A Critical Evaluation of Military and Civilian Regime. Journal of Acta Universitatis Danubius Economics, 9(1), 91101. Retrieved from https://covenantuniversity.edu.ng/Profiles/ Ben-Caleb-Egbide/Budget-Discipline-in-Nigeria-A-Critical-Evaluation-of-Military-and-CivilianRegimes

11. Bhat, A., Kolhar, S., Chellappa, A., \& Anand, H. (2004). Building Budgets from Below. Economic and Political Weekly, Review of Women Studies, 39(44), 4803-4810. Retrieved from https://www.epw. in/journal/2004/44/review-womens-studies-review-issues-specials/ building-budgets-below.html

12. Binswanger, H., Hazell, P., McCalla, A., \& Lutz, E. (1998). Agriculture and the Environment: Perspectives on Sustainable Rural Development. Washington, DC: World Bank Publications. https:// doi.org/10.1596/0-8213-4249-5

13. Boggia, A., Rocchi, L., Paolotti, L., Musotti, F., \& Greco, S. (2014). Assessing Rural Sustainable Development potentialities using a Dominance-based Rough Set Approach. Journal of Environmental Management, 144, 160-167. https://doi.org/10.1016/j. jenvman.2014.05.021
14. Boris, O. H. (2015). Challenges Confronting Local Government in Efficient and Effective social service Delivery: The Nigerian Experience. International Journal of Public Administration and Management Research, 2(5), 1222. Retrieved from https://www. semanticscholar.org/paper/CHALLENGES-CONFRONTING-LOCAL-GOVERNMENT-IN-AND\%3A-Boris/58e3a06f0f788d4aa9fb 0ed114a1d6843342f88d

15. Ebrahim, A. (2003). Making sense of Accountability: Conceptual Perspective for Northern and Southern nonprofits. Nonprofit Management \& Leadership, 14(2), 191-212. https://doi.org/10.1002/ nml.29

16. Egbe, E. J. (2014). Rural and Community Development in Nigeria: An Assessment. IOSR Journal of Humanities and Social Science, 19(3), 104-112. https://doi. org/10.9790/0837-1935104112

17. Egwemi, V., \& Odo, L. U. (2013). Rural Development and Poverty Eradication in Nigeria. Journal of Research in National Development, 11(1), 101-110. Retrieved from https://www.ajol.info/index.php/ jorind/article/view/104168

18. Ehigiamusoe, U. K., \& Umar, A. (2013). Legislative Oversight and Budget Performance in Nigeria: Issues and Policy Options. ISOR Journal of Economics and Finance, 1(5), 1-12. https://doi. org/10.9790/5933-0150112

19. Eteng, F.O. (2005). Rural development in Nigera: Problems and remedies. Sophia: An African Journal of Philosophy, 8(1), 65-71. https://doi.org/10.4314/sophia. v8i1.38656

20. Federal Republic of Nigeria. (1999).Constitution of the Federal Republic of Nigeria. Lagos: Federal Government Press. 
21. Folscher, A., \& Renzio, P. (2017). The Road to Budget Transparency: Learning from Country experience. International Budget Partnership.

22. Glen, S. (n.d.). Slovin's Formula: What is it and When do I use it? StatisticsHowTo.com. Retrieved from https://www.statisticshowto. com/how-to-use-slovins-formula/

23. Goddard, A. (2005).

Accountability and NPM in UK Local GovernmentContributions Towards Governance and Accountability. Financial Accountability \& Management, 21(2), 191-218. https://doi.org/10.1111/j.14680408.2005.00215.x

24. Horngren, C. T. (2013). Management and Cost Accounting ( $5^{\text {th }}$ ed.). Pearson Higher.

25. Horny, A. S. (2000). Oxford Advanced Learners Dictionary of Current English. New York: Oxford Press.

26. Ibenegbu, G. (2017, April 11). Rural development in Nigeria since independence. Legit. Retrieved January 27, 2020, from https:// www.legit.ng/1098547-rural-development-nigeria-independence. html

27. Igboeche, P. O. I. (2017). National Budget and Budgeting in Nigeria: A Critical analysis of 2016 Budget. International Journal of research Arts and Social Sciences, 9(2), 50-61.

28. Jatau, U.V. (2008). Budget Performance, Evaluation, Monitoring and Control in A Challenging Environment. The Nigerian Accounting Horizon, 2(1), 191-196.

29. Iwala, O. S. (2014). Achieving Sustainable Poverty Reduction and Rural Development in Nigeria through local Economic Development Strategies. American Journal of Rural Development,2(1), 13-19. https://doi.org/10.12691/ ajrd-2-1-3

30. Kariuki. (2010). Budgeting: A fundamental management tool. Kasneb Newsline, 1, 4.

31. Khaddafi, M., Raza, H., \& Heikal, M. (2015). Effect of
Budgetary Participation and budget Adequacy on Individual Performance with Job Satisfaction as an Intervening Variable. International Journal of Economics, Commerce and Management, 3(2), 1-15. Retrieved from http:// ijecm.co.uk/wp-content/uploads/2015/02/3226.pdf

32. Kluvers, R., \& Tipett, J. (2010). Mechanisms of Accountability in Local Government: An Exploratory Study. International Journal of Business and Management, 5(7), 46-53. https:// doi.org/10.5539/ijbm.v5n7p46

33. Kpedor, G. (2012). Budgeting, Budgetary Control, and Performance Evaluation: A case study of Allterrain Service Group (ATS) (Master's Thesis). Kwame Nkrumah University of Science and Technology. Retrieved from https://www.academia. edu/23164309/Budgeting_Budgetary_Control_and_Performance Evaluation_A_Case_Study_of_ Allterrain_Service_Group_ATS

34. Madugba, J. U., Ben-Caleb, E., Agburuga, U. T., Obadiaru, D. E., Ani, W. U., \& Ben-caleb, J.O. (2020).Optimal Tax Behaviour and Corporate Survival: The Nigeria Experience. Research in World Economy, 11(6). https://doi. org/10.5430/rwe.v11n6p108

35. Meador, J. E., \& Skerratt, S. (2017). On a unified theory of development: New institutional economics \& the charismatic leader. Journal of Rural Studies, 53, 144-155. https://doi.org/10.1016/j. jrurstud.2017.05.007

36. Moseley, M. J. (2003). Rural Development: Principles and Practice. London, UK: SAGE.

37. Neumeier, S. (2012). Why do Social Innovations in Rural Development Matter and Should They be Considered More Seriously in Rural Development Research? Proposal for a Stronger Focus on Social Innovations in Rural Development Research. Sociologia Ruralis, 52(1), 48-69. https://doi.org/10.1111/j.14679523.2011.00553.x

38. Nwagboso, I. C., \& Duke, O. (2012). Rural Development
Programme Implementation in Developing Countries: The Experience of China and India. Global Journal of Human Social Science sociology, Economics and Political Science, 12(11), 27-34. Retrieved from https:// www.academia.edu/33570384/ Rural_Development_Programme_ Implementation_in_Developing_Countries_The_Experience_ of_China_and_India

39. Nwankpa, L. O., \& Okeke, R. C. (2017). Budgeting for change in the Nigerian Public Sector: a Qualitative Research. Africa Research Review, 11(4), 7-16. https://doi.org/10.4314/afrrev. v11i4.2

40. Ogunkoya, O. A., Lasisi, J. O., Hassan, B., \& Elumah, L. O. (2015). An Integrated Approach to Rural Development in Nigeria. International Journal of African and Asian Studies, 11, 78-83. Retrieved from https://iiste.org/ Journals/index.php/JAAS/article/ view/23938/24509

41. Ojeh, V. N., Origho, T., \& John, P. H. (2012). Agriculture as an Index of Socio-Economic Development of Delta State of Nigeria. World Environment, 2(4), 26-68. https:// doi.org/10.5923/j.env.20120204.02

42. Okoli, F. C., \& Onah, F.O. (2002). Public Administration in Nigeria: Nature, Principles, and Application. Enugu: John Jacob's Classic Publishers. Retrieved from https://searchworks.stanford.edu/ view/5970634

43. Okpanachi, J., \& Mohammad, N. A. (2013). Budget Target Setting and Effective Performance Measurement in Nigerian Hospitality Industry. Journal of Finance \& Economics, 1(3), 3950. Retrieved from https://www. academia.edu/30488251/Budget_Target_Setting_and_Effective_Performance_Measurement_ in_Nigerian_Hospitality_Industry

44. Olaoye, O.F. (2010). Budget Discipline in Government: A key to Building and Sustaining Buoyant External Reserves. The Social Sciences, 5, 386-390. https://doi.org/10.3923/sscience.2010.386.390 
45. Olejniczak, D. B., Olejniczak, J., \& Svobodová, L. (2020). How a Participatory Budget Can Support Sustainable Rural Development - Lessons From Poland. Sustainability, 12(7), 2620. https:// doi.org/10.3390/su12072620

46. Olomola, A. S. (2012). State Budgetary Allocations: An Appraisal of Budget Implementation and Effects in Nigeria (Paper). NISER Research Seminar Series, Ibadan.

47. Olomola, A. S. (2018). Participatoryframework for the proposed Evaluation of the Budget Process effectiveness in Nigeria (Paper). Nigerian Institute of Social and Economic Research (NISER).

48. Onuigbo, R.A., \& Eme, I. (2015). State Governors and Revenue Allocation Formula in Nigeria: A case of The Fourth Republic. International Journal of Accounting Research, 2(7), 14-36. Retrieved from https://www.arabianjbmr. $\mathrm{com} / \mathrm{pdfs} /$ AC_VOL_2_7/2.pdf

49. Osanyintuyi, T.A. (2007). Budgeting and Development Policy in Nigeria. Scribd. Retrieved February 8, 2011, from http:// www.scribd.com/doc/38540444

50. Pollant, J. (2001). SPSS Survival Manual: A Step by Step Guide to Data Analysis Using SPSS. Buckingham, Philadelphia: Open University Press. Retrieved from https://www.academia. edu/2044894/SPSS_survival_ manual_A_step_by_step_guide_ to_data_analysis_using_SP

51. Paul, S. O., Agba, M. S., \& Chukwurah, D. C. (2014). Rural Development Programs and Rural Underdevelopment in Nigeria: A Rethink. International Journal of Public Administration and Management Research, 2(4), 1-14. Retrieved from http://rcmss. com/2015/ijpamr/RURAL\%20 DEVELOPMENT\%20PROGRAMMES\%20AND\%20 RURAL\%20UNDERDEVELOPMENT\%20IN\%20NIGERIA.pdf

52. Rabiu, A. S., Goni, K., Alhaji, A. M., \& Aliyu, M. T. (2015). The role of budget and budgetary control on organizational performance: A case study of Tahir Guest House, Kano State, Nigeria. Journal of Business Management and Economics, 3(4). Retrieved from http://www.innovativejournal.in/ index.php/jbme/article/view/1596

53. Sam-Tsokwa, A.T., \& Ngara, C. O. (2016).The National Assembly and the Budget Process in Nigeria's Fourth Republic: Tackling the Challenges of Timeliness. Canadian Social Science, 12(5), 1-7. http://dx.doi.org/10.3968/8458

54. Stotstky, J. G. (2016). Gender Budgeting: Fiscal Context and Current Outcomes (IMF Working Paper No. WP/16/149). Washington D.C: The International Monetary Fund. Retrieved from https://www.imf. org/external/pubs/ft/wp/2016/ wp16149.pdf

55. Suarez, A. (2019). Towards a Characterization of Sustainable Rural Development: A Systematic Review. Retrieved December 30, 2019, from https://www. researchgate.net/publication/333384812_Towards_a_ Characterization_of_Sustainable_Rural_Development_A_Systematic_Review

56. Szesciło, D., \& Wilk, B. (2018). Can Top Down Participatory Budgeting Work? The Case of Polish Community Fund. Central European Public Administration Review, 16(2), 179-192. https://doi.org/10.17573/ cepar.2018.2.09

57. Tabachnick, B. G., \& Fidell, L. S. (2001). Using multivariate statistics (4th ed.). New York: HarperCollins.

58. Uchechukwu, N., \& Obiora, O C. (2016). Local Government Finances and Rural Development: A Case of Umuahia North Local Government Area of Abia State. Global Journal of Political Science and Administration, 4(5), 32-38. Retrieved from https:// www.eajournals.org/journals/ global-journal-of-political-science-and-administration-gjpsa/ vol-4-issue-5-december-2016/ local-government-finance-ruraldevelopment-case-umuahianorth-local-government-areaabia-state/
59. Uguru, L. C. (2016). Instrument of Control and Accountability in Ebonyi State Local Government Councils, Nigeria. ISOR Journal of Economics and Finance, 7(5), 2127. Retrieved from https://smartlib.umri.ac.id/assets/uploads/files/ b1c33-d0705032127.pdf

60. Ugwuanyi, U. B., \& Ebe, E.C. (2012). Impact of poor Accounting Practices on Budget Implementation of Governmentowned Industries. A study of Enugu State. Research Journal and Accounting, 3(11), 8-15. Retrieved from https://www.iiste.org/Journals/index.php/RJFA/article/ view/3808

61. Weihrich, H., \& Koontz, H. (2003). Management: A Global Perspective. New Delhi: Tata McGraw-Hill. 